\title{
The Effect of Relationship Quality on Customer Advocacy: The Mediating Role of Loyalty
}

\author{
${ }^{1}$ Susanta, ${ }^{2}$ Taher Alhabsji, ${ }^{3}$ M.S. Idrus, ${ }^{4}$ Umar Nimran \\ ${ }^{I}$ Social and Political Science Faculty, UPN "Veteran" Yogyakarta University, Indonesia \\ ${ }^{2,4}$ Administrative Science Faculty, Brawijaya University, Indonesia \\ ${ }^{3}$ Economics and Business Faculty, Brawijaya University, Indonesia
}

\begin{abstract}
Advocacy is a strategic choice for companies responding to the new reality that customers power increased. Potential customers see information from peers or even strangers as less biased and reliable than those of an economic entity. Thus, the information conveyed by a satisfied customer is more believable than that delivered by the business entity. Customer advocacy is very important in the company's efforts to get new customers. Based on social exchange theory, advocacy can be generated from the satisfaction, trust, commitment and loyalty. The purpose of this study was to analyze the influence of satisfaction, trust and commitment to loyalty and its impact on customer advocacy. The hypotheses were tested with structural equation modeling using survey data from 178 customers of a commercial bank in Indonesia. Satisfaction and commitment have direct effect on advocacy, but trust hasn't. Loyalty mediates the relationship between trust and advocacy, while commitment has the greatest effect on advocacy. Findings hold implications for future research as well as for managerial practice
\end{abstract}

Keywords: advocacy, commitment, loyalty, satisfaction, trust.

\section{INTRODUCTION}

Marketing mix management paradigm has dominated the thinking and practice of marketing from 1950 until at least the mid-1990s. This paradigm view of marketing as a management function, in which marketers manipulating marketing mix variables to satisfy customers and create profit. The basic analysis unit is transactions in a competitive market, where the company fully integrated and controls almost all factors of production. The company assumed independent of the environment, thus, the main issue concerning the allocation of marketing resources is formulated in the product, place, price and promotion to attract new customers. Today, this paradigm is beginning to lose its position [1]. New approaches have been emerging in marketing research. Relationship building and management, or what has been labeled relationship marketing, is one leading new approach to marketing which eventually has entered the marketing literature. The concept of relationship marketing was firstly defined in 1983 by Berry and Parasuraman [2] as formation, protection and increase of customer relationships in business.

Managing the relationship has become the core of marketing. With quality products and services into a common standard in many industries and is no longer a major source of competitive advantage, organizations adopt a relationship marketing as a means to differentiate themselves. Based on the fact that it's cheaper to maintain a satisfied customer than attract a new one, marketers focus on attracting and retaining profitable customers, by building long-term relationships for mutual benefit. From an initial focus on how companies can attract, retain, and enhance customer relationships [3], relationship marketing has expanded to explore the relationship between companies and buyers, suppliers, employees, and regulators [4]. Customers, however, are at the center of relationship marketing. A company's relationship with its customers determines the success of the company [5]. Customer retention is a core concept in relationship marketing, which focuses on how to maintain long-term customer relationships rather than how to attracting new customers [6].

In relationship marketing, satisfaction is only one of a number of relational constructs (e.g. Components of commitment, trust) that will affect important consumer behaviors including customer retention, willingness to enhance the relationship, price sensitivity and advocacy [4], [7] [8]. According to Selvi [9] the main objective of relationship marketing is to obtain customer's loyalty by establishing long-term and mutually beneficial relationships between the organization and its customers. By focusing on delighting target customers, companies keep them loyal and eventually turn them into advocates who attract others who value the same things [10]. Customer advocacy is very important in the company's efforts to attract new customers. Advocacy is the willingness of the customer to give strong recommendations and praise to other consumers on behalf of a products or service supplier [11], [12]. When consumers enthusiastically provide positive recommendations on products, services or brands, they are acting as advocates on behalf of that object [13], [14], [15]. Advocacy is a strategic choice for companies responding to the new reality that customers control, not manufacturers and 
distributors. Prospective customers believe information from peers or even strangers as less biased and reliable than those of an economic entity [16]

The purpose of this paper is to understand the drivers of advocacy from a relationship marketing perspective. This study uses a social exchange perspective as the framework to understand why customers become advocates on behalf of their provider. The approach of this study is to examine social situational factors (i.e., the exchange relationship). The social exchange framework is appropriate as it is a useful way to investigate person environment relations [17]. The social exchange framework focuses on relationships between individuals and networks, organization, and corporations [18]. The goal of exchange frameworks is to explain ongoing social relationships by focusing on the quality and content of what is given up and gained. According to Blau [19], exchange relationships as being motivated by rewarding actions. Cook and Rice [20] viewed social exchange research focuses on examining the relationship between social exchange frameworks and constructs such as social networks, perceived justice, trust, affect and emotion.

\subsection{Social Exchange Theory}

Social exchange theory grew out of the intersection of economics, psychology, and sociology. It was developed to understand the social behavior of humans in economic undertakings [21]. Exchange theory is based on the premise that human behavior or social interaction is an exchange of activity, tangible and intangible [22]. Exchange not only permeates the market but also the non-economic realm [19]. Exchange is defined as social interaction characterized by reciprocal stimuli. In consequence, exchange theory examines the processes of establishing and sustaining reciprocity in social relations, or the mutual gratifications between individuals [23].

Several perspectives within the social exchange framework have developed assumptions and propositions [21], [24]. Summarizing the major tenets of social exchange, Cook, Cheshire, and Gerbasi [25] described four main assumptions of social exchange frameworks, while Lee Mohamad and Ramayah describe two assumptions of social exchange [23]. A fundamental assumption of many social exchange frameworks states that actors engage in exchange relationships motivated by the desire to increase gain and avoid loss. Gains may be associated with economic benefits and social benefits. Loss may be associated with the financial costs, equipment and the amount of time invested. Blau [19] states that SET is it assumes that exchange parties intend to obtain benefits from their relationships that would not be achievable on their own. Benefits can also include non-economic rewards derived from increasing their partner's utility [26]. This is perhaps the most widely articulated aspect of social exchange.

The second main assumption suggests exchange relationships develop based on mutual dependence. In other words, actors enter relationships to achieve outcomes they could not achieve alone. The customers and their provider become mutually dependent on one another to achieve separate but complementary goals. Building upon this assumption, Emerson [27] referred to productive exchanges where the actors in the exchange relationship work together to produce an end product or outcome that is shared and valued by both parties.

The third assumption states that exchange relationships are reoccurring, develop over time, and consist of specific partners. This is also one of the key distinctions between social and economic exchanges whereby the later focuses on one time transactions.

The final assumption is based on the economic concept of law of diminishing returns, also discussed in psychology as deprivation satiation. These principles hold that the outcomes, benefits, or rewards one seeks must expand and change over time. An actor will disengage from an exchange relationship if the value of the outcomes remains stagnant over time. This is a continuation of the previous assumption that relationships develop over time; and if in these exchange relations new rewards or benefits are not received, this assumption holds the relationship will terminate.

\subsection{Customer Advocacy}

Advocacy is the willingness of the customer to give strong recommendations and praise to other consumers on behalf of a products or service supplier [28], [29]. When consumers enthusiastically provide positive recommendations on products, services or brands, they are acting as advocates on behalf of that object [13], [14], [15]. Advocacy is a major step forward in the evolving relationship between a firm and its customers. Customer advocacy can be viewed as the top of a pyramid. Total quality management and customer satisfaction are at the base of the pyramid. The growth in customer power and the new marketing strategies of firms require that scholars examine their research strategies. The philosophy of marketing is different. Traditional marketing will be based on understanding customers' needs and then convincing them to buy the firm's products, but advocacy is based on maximizing the customers' interests and partnering with customers [30].

The dictionary definition of "advocate" is "plead for, defend, champion, recommend, support." This is much more than customers who come back time and time again. Advocates are people who are prepared to 
argue your case. They are willing to offer their support as well as their business [31]. Altruism concept explain that advocacy is a behavior provide valuable information for the other party voluntarily without expecting compensation directly or indirectly as a moral obligation that a person must provide benefits for others. From the perspective of organizational citizenship behavior voluntary advocacy is unrelated to the organization's reward. Based on the theory of impression management advocacy is to influence the behavior of others by showing his favorite against an object and condition themselves better so that others will follow.

Advocacy research is important because it will be the strategy of business choice for responding to the new realities that customer hold controls of the company. Potential customers see information from peers or even strangers as more unbiased and reliable than those of an economic entity [16]. Advocacy is important to get the customer in the center of the low confidence in prospective customers to information from business entities. Maintaining customer is achieved by increasing loyalty, while increasing market share achieved by advocacy.

\subsection{Loyalty}

Customer loyalty is a deeply held commitment to rebuy or repatronize a preferred product or service consistently in the future, despite situational influences and marketing efforts having the potential to cause switching behavior [32]. The main theme in customer relationship marketing is to gain and retain customers [33]. Because of the positive influence that customer loyalty has on profitability, Hennig-Thurau, Gwinner, and Gremler [34] state that customer loyalty is the "primary goal" of relationship marketing. Peng and Wang [35] defines relationship marketing as all marketing activities directed to build customer loyalty (keep and win customers) by providing value to all parties involved in relational exchanges. Development of customer loyalty has become an important focus for research marketing strategy in recent years [36]. It is less expensive to keep a loyal customer than to actively market to new customers and less expensive to maintain a loyal customer relationship than to develop a new one [34]. According Olorunniwo, Hsu and Udo [37], loyal customers affects profitability and overall success of the organization in three ways. First, repeat customer purchases generate revenue for the company, both, organizations can reduce the financial commitment in retaining customers than to recruit new customers and third, loyal and satisfied customers are spreading the good news and recommend the service to others.

Customer loyalty can be classified as brand loyalty, service loyalty, and store loyalty [38]. Approach in measuring loyalty has been changed significantly. At one time, study customer loyalty concentrated mainly on buying behavior; efforts more recent research focused on the perceptions of customers' expectations and attitudes towards loyalty [39]. In the literature, customer loyalty is commonly distinguished in three approaches: (1) behavioral, (2) attitudinal, and (3) combined attitude and behavioral loyalty approach. Oliver's perspective predicts that customers should go through four stages to be a loyal customer [32]. First is a cognitive sense (belief). This customer has to confirm that his expectations about the goods or service are met. Second is the affective sense (favored attitude). Consumers are repeatedly satisfied from purchasing behavior. This leads to the conative stage that consumers have a behavioral intention-trust to a firm and commit deeply to buy. The intention leads to the fourth stage of action. Customers have the desire to overcome obstacles, such as attraction of other competitors or price increase by a firm, to achieve the actual purchase behavior [32].

\subsection{Relationship Quality}

The concept of relationship quality arises from theory and research in the field of relationship marketing [40], [41] in which the ultimate goal is to strengthen already strong relationships and to convert indifferent customers into loyal ones [2]. Relationship quality is defined as when the customers are able to rely on the salesperson's integrity and has confidence in the salesperson's future performance because the level of past performance has been consistently satisfactory [40]. Relationship quality can be regarded as a metaconstruct composed of several key components reflecting the overall nature of relationships between companies and consumers. Although there is not a common consensus regarding the conceptualization of relationship quality, there has been considerable speculation as to the central constructs comprising this overarching relational construct [34].

Relationships quality are the high-level construct consisting of several first-order constructs, among which the most commonly used is trust, satisfaction with the seller and a commitment to relation [42], [43]. The origins of the early three constructs lies in studies that focus on the consumer market. Although this construct has also been used extensively in the context of business-to-business, Woo and Ennew [43] warned that if they represent the most appropriate concept for this context remains open to debate. Athanasopoulou, [42] have conducted a meta analysis of 64 articles from 1987 to March 2007 and found that the only areas that were agreed upon three major dimensions of relationship quality: trust, commitment and satisfaction, which has been used in many studies and has been validated in different contexts. 
Satisfaction. Lately customer satisfaction gets new attention in the context of a paradigm shift from transactional marketing to relationship marketing [1]. Relationship satisfaction has been defined as customers' cognitive and affective evaluation based on their personal experience across all service episodes within the relationship [44]. Relationship satisfaction is accumulated across all the interactions in an ongoing relationship. Relationship satisfaction exclusively describes customer satisfaction on the relationship which is the overall assessment the strength of the relationship [45]. There are two types satisfaction: transactional and relational. Transactional satisfaction related to a single transaction [46]. Relational satisfaction regarding the consumption experience [46], [47] and relational satisfaction depends on the kind of transactional satisfaction [48].

In the business market [49] and in the consumer market [50] customers tend to be more satisfied with the provider who carries out efforts by considering customers. Satisfied customer is much more valuable to an organization of service compared with dissatisfied customers [51], thus, the main objective of organization should be to satisfy their customer. When customers are satisfied, they may participate in good behavior to the service providers, which is positive advertising through word of mouth, willingness to recommend, intention to repurchasing, decrease price sensitivity and their willingness to participate in research to help revolutionize the organization [52]. Dissatisfied customer tells an average of nine people about their negative experience. Consequently, the research also found that service organizations lose an average of twelve percent of the annual volume of customers each year due to poor service quality [51]

Trust. Trust is generally regarded as a fundamental element for the success of relationship marketing. Relationships between consumers and companies require trust of to become a long-term relationship [2]. If trust is maintained, the buyer will be remain in the relationship [49]. Hennig-Thurau and Klee [53], Jonsson and Zineldin [54] and Morgan and Hunt [4] define trust as an expectation or willingness to believe that an organization can be relied upon to do what it has promised. The nature of trust in an organizational relationship is the knowledge that the seller will not act in a risky manner that is considered a threat by the buyer [55]. Ganesan [49] states that trust is multidimensional in nature in that it can be attained (or lost) by the seller's keeping (or not keeping) promises to the buyer (credibility) or from not behaving (or behaving) in opportunistic ways that harm the buyer (benevolence).

Commitment. Relationship marketing theory has extensively considered the roles of relationship commitment in customer relationships. Morgan and Hunt (1994) define relational commitment as existing when an exchange partner believes that an ongoing relationship with another is sufficiently important to warrant maximum efforts at maintaining the relationship. Commitment reflects the consumer's voluntary willingness to remain in and make efforts towards maintaining a relationship [56]. Commitment encourages exchange parties to resist short-term benefits in favour of the expected long-term benefits of remaining in the relationship [4]. Commitment can be the result of emotional attachment or cognitive calculation [57], [58]. Relationship commitment is an important component of relational exchanges. Research shows that relationship commitment is at the core of all successful working relationship and it is an important element in successful long-term relationships, including supplier-buyer relationships [59].

\section{CONCEPTUAL FRAMEWORK}

In this section, we develop an integrative model that combines and specifies how the relationship quality may influence the two important relational outcomes of customer loyalty and advocacy. The integrative model is shown in Fig. 1.

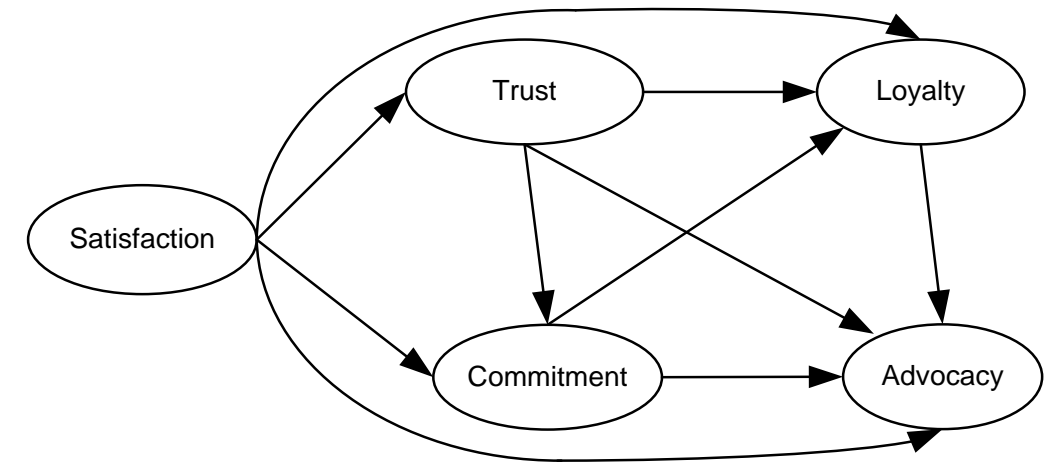

Figure 1. Conceptual Model of Relationship Quality and Advocacy

\subsection{Consequences of Satisfaction}

Several authors hypothesized a positive flow from satisfaction to trust [5], [60], and [40]. Ganesan [49] found strong empirical support for the path from satisfaction to trust. Satisfaction is an antecedent to trust [47]. Satisfaction leads to the belief that the same quality of service will be delivered in future. Moreover, Geyskens' 
[61] meta-analysis as well as recent research [62], [63], revealed that satisfaction positively influences trust. Thus our firs hypothesis:

H1. Relationship satisfaction has positive impact on customers' trust

As Tax et al. [64] showed, satisfaction can lead to commitment, while Hennig-Thurau et al., [34] postulate satisfaction to positively influence commitment. Satisfaction reinforces the users' decision to participate in the services being offered. A high level of satisfaction provides the customer with a repeated positive reinforcement, thus creating commitment. Satisfaction is related to the fulfillment of customers' social needs, and the repeated fulfillment of these social needs is likely to lead to bonds of an emotional kind that also constitute commitment [53]. Hence, we hypothesize that:

H2. Relationship satisfaction has positive impact on relationship commitment

Customer satisfaction and loyalty are highly correlated [65], [66] but form two distinct constructs [67], [32]. The link between satisfaction and loyalty has been examined in many studies. Satisfaction leads to the creation of a strong relationship between the service provider and customer, leading to relationship longevity, or customer retention [1]. Customer satisfaction with the bank relationship is a good basis for loyalty [68]. A metaanalytic review of the literature [69] as well as recent research [70], [71], [63] reveals satisfaction as one of the enduring antecedents of loyalty. Therefore, the following hypothesis is proposed:

H3. Relationship satisfaction has positive impact on customers' loyalty

Evaluation of the relationship is the basis of the maintenance and growth of the relationship. Satisfaction is the result of a positive evaluation for services. Advocacy is a consequence of a positive evaluation of the customer for services [13], [6]. Advocacy is one of the positive consequences of satisfaction in the consumption experience [6]. Anderson [13] found that a delighted customer is more willing to give a recommendation of those who have a neutral satisfaction. Customers become advocates for providers if they continuously comfortable with the level of service from service providers [15]. Satisfaction is considered as a logical antecedent of advocacy [72]. Accordingly, we hypothesize:

H4. Relationship satisfaction has positive impact on customers' advocacy

\subsection{Consequences of Trust}

In relationship marketing literature, trust is generally modeled as a precursor to relationship commitment [4], [57], [47]. Individuals are reluctant to commit themselves unless they have confidence in the service provider's ability to constantly meet their expectations in the future and in its willingness to avoid any behavior that could be detrimental to them. When they distrust a supplier, consumers tend to become less involved in the service relationship and to decrease their potential vulnerability to the partner. Hence, we hypothesize that:

H5. Trust has positive impact on customers' commitment

Trust has been studied widely in the social exchange literature [73], as well as in services marketing [2], and retailing, where Berry [74] proposes that trust is the basis for loyalty. Many authors have found a positive relationship between trust and loyalty. An empirical study by Delgado-Ballester and Munuera-Aleman [75] found that trust had a positive impact on customer loyalty, moderated by customer involvement. Chaudhuri and Holbrook [76], Sirdeshmukh et al. [77], and Harris and Goode [78] found that trust is related to both behavioral loyalty and attitudinal loyalty. Hence, we hypothesize that:

H6: Trust has a positive impact on customers' loyalty.

In accordance with the commitment-trust theory [4] confidence is a key mediator in the relationship's success because it encourages marketers to: (1) acting to secure investments through cooperative relationships with partners, (2) opposing an attractive short-term alternatives and like the expected length term gains, with fixed along with current partners, (3) saw potential high risk action as a prudent, due to the belief that the partner will not act as opportunistic. Trust is the key moderator of the relationship marketing outcomes. Advocacy is considered as an important outcome of effective relationship marketing [72], [15], and [79]. Trust moderates the variable antecedent with advocacy, in other words the trust affect advocacy. The following hypothesis is therefore proposed:

H6: Trust has a positive impact on customers' advocacy.

\subsection{Consequences of Commitment}

Commitment and loyalty are two concepts connected but different. Company commitment is a key antecedent of company loyalty [80]. Committed customers are more likely to remain loyal to the service firm as they feel that the service relationship is important. Commitment to develop positive intentions toward acceptance of a new service provider. Commitment is an important construct in buying behavior and can drive important outcomes, such as reducing the loss of customers and increase motivation. Pritchard et al., [81] found strong support that commitment is a direct antecedent important for customer loyalty in a wide range of business services. In various research commitments affect loyalty [12], [82], [62]. Therefore, we assume that: 
H7: Commitment has a positive impact on customers' loyalty.

If customers feel comfortable dealing with service providers, they are willing to act as an advocate on behalf of service providers [14]. Price and Arnould [83] found that customers who identify themselves with service providers and takes the view that providers are friends, they tend to provide a good recommendation. Brown et al., [84] found the effect of commitment on the positive intentions of word-of-mouth. When a customer has a commitment to the organization, they want the organization to be successful. They feel comfortable recommending the organization to prospective customers, because they believe prospective customers will get benefit as their experiences. We therefore propose that:

H8: Commitment has a positive impact on customers' advocacy.

\subsection{Consequences of Loyalty}

Customer loyalty is understood as a desire to buy the product and continue the relationship with the provider [85] customer loyalty is particularly important because have positive impact on sales, share of wallet and customer retention [86]. Advocacy is the customer's desire to provide strong recommendations and praise for suppliers of products or services to other customers. Consumer behavior research supports the idea that the loyalty and advocacy of different but related constructs. Michael [87] distinguish between loyalty to advocacy by saying that truly loyal customers to become advocates. Attitudinal loyalty has been suggested as a particular predictor of advocating on behalf of an organization or product by informing others of positive experiences and/or recommending said organization or product [38]. We thus hypothesize that:

H8: Loyalty has a positive impact on customers' advocacy.

\subsection{Development of the Measures}

\section{RESEARCH METHOD}

Operationalizations of the variables for the model reflect operationalizations past research employs with some minor modifications. With regard to the exogenous constructs, this study uses a modified and combined scale of Leverin and Liljander [88] and Gaur [89] for satisfaction. Scales for exogenous constructs, this study uses a modified and combined scale of Lee and Chung [90], Dagger and O'Brien [91], and Fullerton [8] for trust, a modified and combined scale of De Wulf [92], Abdul-Muhmin [93], and Dagger and O’Brien [91] for commitment, modified and combined scale of Ndubisi [70]) and Gaur [89], for loyalty and a modified and combined scale of Kim and Gwinner [94] and Fullerton [8] for advocacy. For all scales the respondents had to express their agreement with a given statement using a five-point, Likert-type scale ( 1 = "strongly disagree"; $5=$ "strongly agree"). All variables were measured in a positive direction. Before the data collection process started, the scales were tested on 30 members of the population to ensure have a good validity and reliability.

\subsection{Data Gathering}

Customers of commercial bank in special region of Yogyakarta, Indonesia comprise the study's population. A participating bank allowed its customers to be surveyed in the bank's premises by the researchers. The exercise was conducted on five bank branches over a period of three month, two days a week, Sunday and Friday between 8:30 a.m. and 3 p.m. The timing was designed to suit the time when many customers visit the banks. Customers' participation was not mandatory, thus all the respondents voluntarily supplied the data for the study. Of the 246 customers who accepted the survey, completed and returned it. However, only 178 were usable for this analysis: 68 were excluded because of incomplete data, related with the bank less than two years, or because they were do not make the bank as primary bank. This resulted in a 72 percent response rate.

\subsection{Data analysis}

The proposed research constructs were then tested with structural equation modeling (SEM). The maximum likelihood method of estimation was adopted. The SEM procedure is appropriate to test the proposed theoretical model because an evaluation is then possible of how well the proposed conceptual model that contains observed variables and unobserved constructs explains or fits the collected data [95], [96].

\subsection{Measurement Model}

\section{RESULT}

All measures were first subjected to exploratory factor analysis and then to confirmatory factor analysis. This was undertaken on the full sample of $n=178$. Exploratory factor analysis results confirmed the factor structure proposed in the research model. All scales were found to be uni-dimensional. Confirmatory factor analysis supported the fit of the measurement model as all items were found to serve as strong measures of their respective construct $\left(x^{2}=213.260, p=0.189, D F=196, \mathrm{CFI}=0.994, \mathrm{IFI}=0.994\right.$, RMSEA $\left.=0.022\right)$. Analysis also revealed adequate levels of construct reliability with estimates exceeding 0.80 and average 
variance extracted exceeding 0.50 . The discriminant validity of all measures was established. Discriminant validity is provided in Table I, while scale reliability and average variance extracted are shown in Table II.

Table I

Discriminant validity

\begin{tabular}{lccccc}
\hline & Satisfaction & Trust & Commitment & Loyalty & Advocacy \\
\hline Satisfaction & 0.807 & & & & \\
Trust & 0.645 & 0.868 & & & \\
Commitment & 0.564 & 0.658 & 0.745 & & \\
Loyalty & 0.593 & 0.642 & 0.528 & 0.761 & \\
Advocacy & 0.531 & 0.565 & 0.566 & 0.572 & 0.777 \\
\hline
\end{tabular}

Table II

Parameter estimates, construct reliability and average variance extracted

\begin{tabular}{lcccc}
\hline & $\begin{array}{c}\text { Cronbach's } \\
\text { alpha }\end{array}$ & $\begin{array}{c}\text { Range of } \\
\text { parameter } \\
\text { estimates }\end{array}$ & $\begin{array}{c}\text { Construct } \\
\text { Reliability }\end{array}$ & $\begin{array}{c}\text { Average } \\
\text { variance } \\
\text { extracted }\end{array}$ \\
\hline Satisfaction & 0,867 & $0.696-0.945^{* * *}$ & 0.881 & 0.652 \\
Trust & 0,938 & $0.804-0.920^{* * *}$ & 0,938 & 0.753 \\
Commitment & 0.871 & $0.721-0.808^{* * *}$ & 0.862 & 0.555 \\
Loyalty & 0.856 & $0.715-0.798^{* * *}$ & 0.873 & 0.579 \\
Advocacy & 0.863 & $0.712-0.871^{* * *}$ & 0.858 & 0.603 \\
\hline
\end{tabular}

Note: $* * * p<0.001$

\subsection{Structural Model}

A similar set of fit indices was used to examine the structural model. Comparison of all fit indices, with Their corresponding recommended values, provided evidence of a good model fit $\left(\chi^{2}=213.260, p=0.189, D F\right.$ $=196, \mathrm{CFI}=0.994, \mathrm{IFI}=0.994, \mathrm{RMSEA}=0.022$ ) Thus, we could proceed to examine the path coefficients of the structural model.

Properties of the causal paths, including standardized path coefficients, are shown in Fig. 2. The effect of customer satisfaction on customers' trust was significant $(\beta=0.634, \mathrm{P}<0.05)$, similarly customers' satisfaction had a positive and significant impact on customers' commitment $(\beta=0.316, \mathrm{P}<0.05)$, loyalty $(\beta=$ $0.262, \mathrm{P}<0.05$ ) and customer's advocacy. Thus, H1, H2 and H3 were supported.

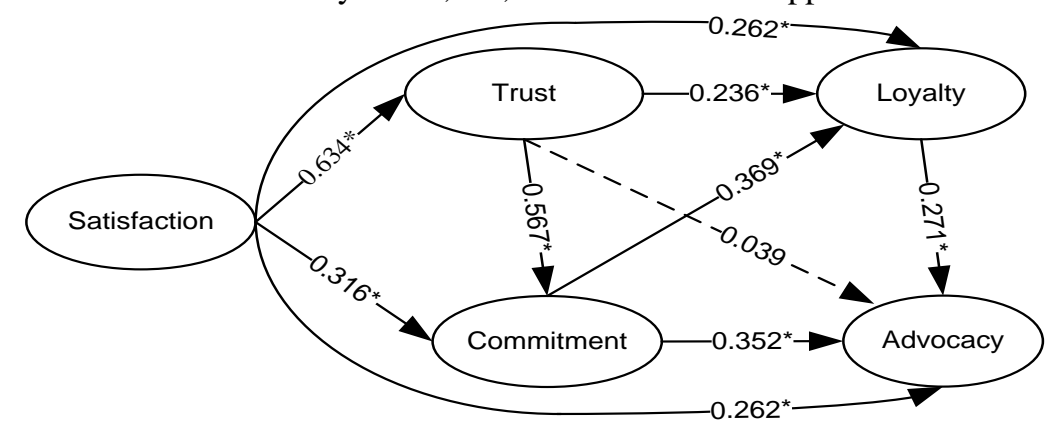

Figure 2. Path diagram of integrative model results

Note: Asterisks indicate significant result

As expected, trust had a positive and highly significant impact on both customers' commitment $(\beta=$ $0.316, \mathrm{p}<0.05)$ and customers' loyalty $(\beta=0.236, \mathrm{p}<0.05)$. Therefore, $\mathrm{H} 4$ and $\mathrm{H} 5$ were also supported. Contrary to the proposed relationship, the influences trust on customers' advocacy is not significant $(\beta=0.039$, $\mathrm{p}>0.05$ ), rejecting H6. Commitment was found to be a significant factor in determining customer' loyalty $(\beta=$ $0.369, \mathrm{p}<0.05)$ and customer' advocacy $(\beta=0.351, \mathrm{p}<0.05)$, supporting hypotheses H7 and H8. Finally, customer loyalty appeared to be a significant determinant of customers' advocacy $(\beta=0.271, \mathrm{p}<0.05)$, supporting $\mathrm{H} 9$.

Commitment exerting a stronger direct effect on customer advocacy than satisfaction, trust, or loyalty. The total effect of on customers' advocacy was 0.452 . However, the total effect of customers' satisfaction on 
customers' advocacy was 0.703. Commitment showing a stronger direct effect, but and customers' satisfaction exhibited a stronger total effect on customers' advocacy loyalty than that of commitment. The direct, indirect, and total effect of customers' satisfaction, trust, commitment, loyalty and advocacy were summarized in Table III.

Table III

The direct, indirect, and total effect of dominants on customers' advocacy

\begin{tabular}{lccc}
\hline & \multicolumn{3}{c}{ Advocacy } \\
\cline { 2 - 4 } & Direct effect & Indirect effect & Total effect \\
\hline Satisfaction & 0.262 & 0.441 & 0.703 \\
Trust & 0.039 & 0.320 & 0.359 \\
Commitment & 0.352 & 0.100 & 0.452 \\
Loyalty & 0.271 & & 0.271 \\
\hline
\end{tabular}

Focusing on the indirect effects of satisfaction, trust and commitment on advocacy, it was apparent that these effects are mediated through loyalty. In order to evaluate the mediating role of loyalty (LO), multiple regression analyses have been carried out using the average of the indicators for the multiple items latent variables (satisfaction (ST), trust (TR), commitment (CO) and advocacy (AD)). To test mediation, one should estimate the three following regression equations as proposed by Baron and Kenny [97]:

(1) Regressing the mediator on the independent variable.

(2) Regressing the dependent variable on the independent variable.

(3) Regressing the dependent variable on both the independent variable and the mediator.

To establish mediation, the following conditions must hold [82]: first, the independent variable must affect the mediator in the first regression; second, the independent variable needs to affect the dependent variable; and third, the mediator must affect the dependent variable in the third equation. If all these conditions hold in the predicted direction, then the effect of the independent variable on the dependent variable must be less in the third equation than in the second. Perfect mediation exists if the independent variable has no effect when the mediator is controlled:

(1) In $\mathrm{LO}=\alpha_{1}+\beta_{1} * \mathrm{ST}+\varepsilon_{1}, \quad \beta_{1}$ must be significant.

(2) In $\mathrm{AD}=\alpha_{2}+\beta_{2} * \mathrm{ST}+\varepsilon_{2}, \quad \beta_{2}$ must be significant.

(3) In $\mathrm{AD}=\alpha_{3}+\beta_{\mathrm{ST}} * \mathrm{ST}+\beta_{\mathrm{LO}} * \mathrm{LO}+\varepsilon_{3}, \quad \beta_{\mathrm{ST}}$ and $\beta_{\mathrm{LO}}$ must be significant and $\beta_{\mathrm{ST}}<\beta_{2}$.

The results of Table IV demonstrate that in all cases loyalty is a partial mediator between satisfaction, trust, commitment and advocacy.

Table IV

Test of the mediator effect of loyalty in the relationship between satisfaction, trust, commitment and advocacy

\begin{tabular}{|c|c|c|c|c|c|}
\hline \multicolumn{3}{|c|}{ Variable } & \multirow{2}{*}{$\beta_{1}$ signif.? } & \multirow{2}{*}{$\beta_{2}$ signif.? } & \multirow{2}{*}{$\begin{array}{l}\beta_{\mathrm{ST}}, \beta_{\mathrm{TR}}, \beta_{\mathrm{CO}}, \text { and } \beta_{\mathrm{LO}} \text { signif.? } \\
\text { and } \beta_{\mathrm{ST}}, \beta_{\mathrm{TR}}, \beta_{\mathrm{CO}},<\beta_{2} \text { ? }\end{array}$} \\
\hline Indep. & Med. & Depen. & & & \\
\hline ST & LO & $\mathrm{AD}$ & $t=9.759$ & $t=8.319$ & $t_{\mathrm{ST}}=4.027, t_{\mathrm{LO}}=5.378 ; \beta_{\mathrm{ST}}(0.281)<\beta_{2}(0.503)$ \\
\hline TR & LO & $\mathrm{AD}$ & $t=11.119$ & $t=9.082$ & $t_{\mathrm{TR}}=4.379, t_{\mathrm{LO}}=4.635 ; \beta_{\mathrm{TR}}(0.315)<\beta_{2}(0.529)$ \\
\hline $\mathrm{CO}$ & LO & $\mathrm{AD}$ & $t=8.249$ & $t=9.101$ & $t_{\mathrm{CO}}=5.411, t_{\mathrm{LO}}=5.603 ; \beta_{\mathrm{CO}}(0.374)<\beta_{2}(0.578)$ \\
\hline
\end{tabular}

Note: Indep.: Independent; Med.: Mediator; Depen.: Dependent; signif.: Significant; ST: Satisfaction; LO: Loyalty; AD: advocacy; TR: Trust; CO: Commitment

\section{CONCLUSION}

While the need to proactively manage customers' advocacy has been increasingly recognized within marketing, its antecedents are not well understood. The present study merges relationship marketing and advocacy marketing literature to address how loyalty moderates the relationship between relationship quality and customer advocacy in a banking context. To the authors' knowledge, this study is the first time these constructs have been examined in an integrated approach. Understanding this process is important given that loyalty is the main purpose of relationship marketing and customer advocacy can greatly extend the effectiveness and efficiency of an organization's marketing efforts. Results of the present research suggest that it is the combined influence of relationship quality and loyalty that is important in understanding customer advocacy.

These findings contribute to the extant literature in several ways. First, the research extends thinking from the relationship marketing to deepening understanding of customer's advocacy. This study shows that the role relationship quality and loyalty in developing customer advocacy. Given its impact on advocacy, relationship quality from the banking should enhance episodic value in relationships for the customer which is implicated in satisfaction, trust and commitment [42]. Future research could examine other aspects of relationship quality beyond the satisfaction, trust and commitment, such as conflict in various forms (affective, 
manifest, calculative, functional, dysfunctional), cooperation, opportunism, power, adaptation, atmosphere, and social and/or structural bonds [42]

A second contribution of the research relates to the exploration of loyalty as moderator between relationship quality and advocacy. Consumer research [98] has suggested that a customer's intention to inform friends, family, and other potential customers of their experiences with a company or product is related to the development of loyalty to the product or company. However, there remains confusion as to how this phenomenon relates to loyalty, it has been included in studies as an aspect of attitudinal loyalty [99], as distinct from loyalty [14], as a mediating variable between commitment and behavioral loyalty [100] and as a loyalty outcome [101]. The current study termed this phenomenon intent to advocate and studied the construct as its own dependent variable, discreet from loyalty. However, the results of this study indicated that advocate may be best understood as a loyalty outcome. The current study indicates that three relationship quality construct: satisfaction, trust and commitment were predictors of customers' advocacy.

Future research could also explore if trust really have no significant effect on advocacy. Literature review showed that trust engenders advocacy. Trust has been implicated in organizational citizenship behaviors [102]. Trust engenders a sense of obligation that translates to extra-role behaviors [103]. Advocacy motivation can be explained from the concept of altruism and organizational citizenship [104] and customer citizenship behavior [105]. Generally these concepts explain individual journey through the roles needed to help others, to volunteer for assignments that are difficult or unpleasant, or engage in spontaneous action, cooperation, protection, and assistance to others [106]. However, the results of this study indicate that trust has no significant effect on advocacy.

A final contribution relates to advocacy as a focal construct. Future research could extend this emphasis in exploring how advocacy could contribute to customer acquisition. Advocacy is the readiness of customers to prefer a supplier and then refer friends, relatives, and colleagues [10]. Advocacy translates into retention, increased share of wallet, and higher levels of acquisition. The ultimate test of a relationship provider and customer is the customer willing to be an advocate on behalf of provider and defend the provider from other party detractors [107]. Research findings indicate an important role of satisfaction on advocacy. Provider can create advocacy by creating such a differentiated experience that customers become the best salespeople on behalf provider. Advocacy can built through a satisfying experience and value they offer customers. Providers can deliver a customer experience that is consistent, intentional, differentiated, and valuable.

This study has several limitations. Because the context of the study is the banking industry, one may argue that this study is not generalizeable and is not applicable to other industries. Banking is an industry that more relies upon positive word-of mouth and reputation than depend on mass advertising to promote its services. Although this study may not be generalizeable to all service industries, the results in this study are highly conclusive of the banking industry. In response to this limitation, a future research suggestion may lie in trying to replicate this study in other contexts such as the hotel, educational or food and beverage industries

A second limitation to this study is based on demographic issues inherent in the sample. A gender bias may exist where 122 customers out of a sample of 178 , are male. This was due the relationship with the bank especially in the rural areas in Indonesia is mostly done by male. This limitation calls for future research direction in studying gender bias in advocacy in a context that is gender bias-free like the food and beverage industries or the retail industry. Similar to the gender bias. The sample was drawn from one regional privilege in Indonesia. Cultural differences may exist in customers and their willingness to talk about their service experience. It would be interesting to do a cross- cultural comparison among two very different cultures such as the differences existent in behavioral intentions between province or nation.

This study tested satisfaction, trust and commitment as an antecedent of loyalty. In fact there are other constructs that contribute to the variance in customer loyalty. This study only identifies and tests the behavioral outcome in the form of advocacy. In fact there are other behavioral outcomes that are directly caused by the level of customer loyalty. Future studies could extend this research by adding constructs net promoter score [108] as the outcome of advocacy. Net promoter score is a quantitative measure of how much the customer is willing to be an advocate (promoter), passive, and detractors.

\section{REFERENCES}

[1] Grönroos, C., From marketing mix to relationship marketing: towards a paradigm shift in marketing, Management Decision, Vol. 32 No. 2, 1994, 4-20.

[2] Berry, L. L. and Parasuraman, A. Marketing Services. Competing Through Quality. (Lexington, MA: Free Press/Lexington Books, 1991).

[3] Berry, L. L. Relationship marketing, in Berry, L.L., Shostack, G.L. and Upah, G.D. (Eds), Emerging Perspectives on Services Marketing, (Chicago, IL: American Marketing Association, 1983) 25-8.

[4] Morgan, R. M. and Hunt, S.D., The commitment trust theory of relationship marketing, Journal of Marketing, Vol. 58, July 1994, 20-38 
[5] Bendapudi, N. and Berry, L., Customers' motivations for maintaining relationship with service providers. Journal of Retailing, 73(1), 1997, 15-37.

[6] Zeithaml, V. A. and Bitner, M. J. Services marketing. (New York: McGraw Hill, 1996).

[7] Bansal, H. S., Irving, P. G., and Taylor, S. F., A three-component model of customer commitment to service providers. Journal of the Academy of Marketing Science, 32(3), 2004, 234-250.

[8] Fullerton. G., Creating advocates: The roles of satisfaction, trust and commitment, Journal of Retailing and Consumer Services, Vol. 18 Issue 1, 2011, 92-100.

[9] Selvi, M. S., Relationship marketing "Strategies and techniques". ( Ankara Detay Press, 2007).

[10] Smith, S. and Wheeler, J., Managing the customer experience, Turning customers into advocates (New York: Prentice Hall, 2002).

[11] Hill, S., Provost, F., Volinsky, C., Network based marketing: identifying likely adopters via consumer networks. Statistical Sciences 21 (2), 2006, 256-276.

[12] Harrison-Walker, J., The measurement of word-of-mouth communication and an investigation of service quality and customer commitment as potential antecedents. Journal of Service Research 4 (1), 2001, 60-75.

[13] Anderson, E., Customer satisfaction and word of mouth. Journal of Service Research 1 (1), 1998, 5-17.

[14] Fullerton, G., When does commitment lead to loyalty? Journal of Service Research, 5(4), 2003, 333-344.

[15] White, S.S. and Schneider, B., Climbing the commitment ladder: the role of expectations disconfirmation on consumer's behavioral intention, Journal of Service Research, 2 (3), 2000, 240-253

[16] Brown, Jacqueline J. and Peter H. Reingen, Social ties and word-of-mouth referral behavior, Joumal of Consumer Research, 14, 1987, 350-362.

[17] Emerson, Jacqueline J. and Peter H. Reingen, Social ties and word-of-mouth referral behavior, Journal of Consumer Research, $14,1987,350-362$.

[18] Cook, K. S., O'brien, J. O., and Kollock, P., Exchange theory: A blueprint for structure and process, In G. Ritzer (Ed.), Frontiers of social theory the new synthesis (New York: Columbia University Press, 1990)158-181.

[19] Blau, P. M., E x c h a n g e and Power in Social Life (New York.John Wiley and Sons, 1964).

[20] Cook, K. S., and Rice, E., Social exchange theory, In J. Delamater (Ed.), Handbook of Social Psychology (New York: Springer Science Business Media, 2006) 53-76.

[21] Homans, G., C., Social behavior as exchange, American Journal of Sociology, 63, 1958, 597-606.

[22] Homans, G, C., Social Behavior: Its Elementary Forms (New York: Harcourt Brace, 1961)

[23] Lee, J. W. C., Mohamad, O. and Ramayah, T. Outsourcing: is the social exchange theory still relevant in developing countries?, Journal of Research in Interactive Marketing Vol. 4 No. 4, 2010, 316-345

[24] Turner, J, H., The structure of sociological theory (Chicago, IL: Dorsey Press, 1986).

[25] Cook, K. S., Cheshire, C, and Gerbasi, A., Power dependence and social exchange, In P. J. Burke (Ed.), Contemporary social psychological theories (Stanford, CA: Stanford University Press, 2006). 194-216.

[26] Andaleeb, Syed Saad, Dependence relations and the moderating role of trust implications for behavioural intentions in marketing channel, International Journal of Research in Marketing, Vol. 12, 1995, 157-72.

Emerson, R., Social exchange theory, Annual Review of Sociology, 2, 1976, 335-362

[28] Hill, S., Provost, F., Volinsky, C., Network based marketing: identifying likely adopters via consumer networks. Statistical Sciences 21 (2), 2006, 256-276.

[29] Harrison-Walker, J., The measurement of word-of-mouth communication and an investigation of service quality and customer commitment as potential antecedents. Journal of Service Research 4 (1), 2001, 60-75.

[30] Urban, Glen L., The emerging era of customer advocacy, MIT Sloan Management Review, Winter, 2004.

[31] Smith, S. and Wheeler, J, Managing the customer experience, Turning customers into advocates (New York: Prentice Hall, 2002).

[32] Oliver, R. L., Satisfaction: A behavioral perspective on the consumer (London: McGraw-Hill, 1997).

[33] Grönroos, C., Relationship marketing: the strategy continuum. Journal of the Academy of Marketing Science, 23 (4), 1995, 252-254.

[34] Hennig-Thurau, T., Gwinner, K.P., and Gremler, D.D., Understanding relationship marketing outcomes: an integration of relational benefits and relationship quality, Journal of Servive Research, Vol. 4 No. 3, February, 2002, $230-247$.

[35] Peng, Leong Yow and Wang, Qing., Impact of relationship marketing tactics (rmts) on switchers and stayers in a competitive service industry. Journal of Marketing Management, 22, 2006, 25-59.

[36] McMullan, R., A multiple-item scale for measuring customer loyalty development. Journal of Services Marketing, 19(7), 2005, $470-481$.

[37] Olorunniwo, F., Hsu, M. K., and Udo, G. J., Service quality, customer satisfaction, and behavioral intentions in the service factory. Journal of Services Marketing, 20(1), 2006, 59-72.

[38] Dick, A. S., and Basu, A., Customer loyalty: toward an integral framework. Journal of Academic Marketing Science, 22(2), 1994, 99-104.

[39] Mason, D. D. M., Tideswell, C., and Roberts, E., Guest perceptions of hotel loyalty. Journal of Hospitality \& Tourism Research, 30(2), 2006, 191-206.

[40] Crosby, Lawrence A., Kenneth R. Evans, and Deborah Cowles, Relationship quality in services selling: an interpersonal influence perspective, Journal of Marketing, 54, July 1990, 68-81.

[41] Dwyer, F. R., Schurr, P. H., and Oh, S., Developing buyer-seller relationships. Journal of Marketing, 51(2), 1987, 11-27.

[42] Athanasopoulou, Pinelopi, Relationship quality: a critical literature review and research Agenda, European Journal of Marketing, Vol. 43 No. 5/6, 2009, 583-610

[43] Woo, K. and Ennew, C.T., Business-to-business relationship quality: an IMP interaction-based conceptualisation and measurement, European Journal of Marketing, Vol. 38 Nos 9/10, 2004, 1252-71.

[44] Storbacka, K., Strandvik, T. and Grönroos, C., Managing customer relationships for profit: the dynamics of relationship quality, International Journal of Service Industry Management, Vol. 5 No. 5, 1994, 21-38.

[45] Palmatier, Robert W.; Jarvis, Cheryl Burke; Bechkoff, Jennifer R. \& Kardes, Frank R., The role of customer gratitude in relationship marketing, Journal of Marketing, Vol. 73, September 2009, 1-18

[46] Shankar V., Smith A. K. and Rangaswamy A., Customer satisfaction and loyalty in online and offline environments, International Journal, of Research in Marketing, Vol. 20, 2003, 153-175.

[47] Garbarino, E. and Johnson M.S., The different roles of satisfaction, trust, and commitment in customer relationships, Journal of Marketing 63 (2), 1999, 70-87 
[48] Rowe A. T. et Coote L. V., Measuring satisfaction with interpersonal service and self-service technology, ANZMAC 2000 Visionary Marketing for the 21st Century: Facing the Challenge, 2000, 1079-1084

[49] Ganesan, S., Determinants of long-term orientation in buyer-seller relationships. Journal of Marketing, 58, April 1994, 1-19.

[50] Baker, Thomas L., Penny M. Simpson, and Judy A. Siguaw, The Impact of Suppliers' Perceptions of Reseller Market Orientation on Key Relationship Constructs. Journal of the Academy of Marketing Science 27, 1999, 50-57.

[51] Blodgett, J. G., Granbois, D. H., \& Walters, R. G., The effects of perceived justice on complainants' negative word-of-mouth behavior and repatronage intentions. Journal of Retailing, 69, 1993, 399-427.

[52] Luchars, J. Y., and Hinkin, T. R., The service quality audit: A case study, Cornell. Hotel and Restaurant Administration Quarterly, Vol. 37 (1), 1996, 34-41.

[53] Hennig-Thurau, T. and Klee, Alexander, The impact of customer satisfaction and relationship quality on customer retention: A critical reassessment and model development. Psychology \& Marketing, 14, 1997, 737-764.

[54] Jonsson, P. and Zineldin, Achieving high satisfaction in supplier-dealer working relationships. Supply Chain Management, 8 (3/4), 2003, 224-240.

[55] Koeszegi, S.T., Trust-building in inter-organizational negotiations. Journal of Managerial Psychology, 19 (6), $2004,640-660$.

[56] De Wulf, K., Odekerken-Schröder, G. and Dawn Iacobucci, Investments in Consumer Relationships: A cross-country and crossindustry exploration, Journal of Marketing, 65, October 2001, 33-50.

[57] Geyskens, I., Steenkamp, J. -B. E. M., Scheer, L. K., and Kumar, N., The effects of trust and interdependence on relationship commitment: A transatlantic study. International Journal of Research in Marketing, 13(4), 1996, 303-317.

[58] Wetzels, M., De Ruyter, K., and Van Birgelen, M., Marketing service relationships: the role of commitment. Journal of Business \& Industrial Marketing, 13(4/5), 1998, 406-423.

[59] Anderson, C.J. and Narus, J.A., A model of distributor firm and manufacturer firm working relationship, Journal of Marketing, Vol. 54, 1990, 57-62.

[60] Bennett, R., Relationship formation and governance in consumer markets: transactional analysis versus the behaviorist approach. Journal of Marketing Management. vol. 12, no. 5, 1996, 417-436.

[61] Geyskens, I., Steenkamp, J.E.B.M., and Kumar, N., Generalizations about trust in marketing channel relationships using metaanalysis. International Journal of Research in Marketing, 15(3), 1998, 223-248.

[62] Sanchez-Franco, M. J., Ramo, A. F. V. S, and Velicia, F. A. M., The moderating effect of gender on relationship quality and loyalty toward Internet service providers, Information \& Management 46, 2009, 196-202.

[63] Hsu, Chien-Lung; Liu, Chia-Chang and Lee,Yuan-Duen, Effect of commitment and trust towards micro-blogs on consumer behavioral intention: a relationship marketing perspective, International Journal of Electronic Business Management, Vol. 8, No. 4, 2010, 292-303.

[64] S.S. Tax, S.W. Brown, M. Chandrashekaran, Customer evaluations of service complaint experiences: implications for relationship marketing, Journal of Marketing 62 (2), 1998, 60-76.

[65] Athanassopoulos, A., Gounaris, S. and Strathakopoulos, V., Behavioural responses to cuatomer satisfaction: and empirical study, European Journal of Marketing, Vol. 35 No. 5/6, 2001, 687-707.

[66] Hallowell R., The realtionship of customer satisfaction, customer loyalty, and profitability: an empirical study, International Journal of Service Industry Management, Vol. 7 No. 4, 1996, 27-42.

[67] Bennett, R. and Rundle-Thiele, S., Customer satisfaction should not be the only goal, Journal of Service Marketing, Vol. 18 No. 7, 2004, 514-523.

[68] Pont, M. and McQuilken, L., An empirical investigation of customer satisfaction and loyalty across two divergent bank segment, Journal of Financial Service Marketing, Vol. 9 No. 4, 2005, 344-359.

[69] Szymanski, D. M., and Henard, D. H., Customer satisfaction: A meta-analysis of the empirical evidence, Journal of the Academy of Marketing Science, Vol. 29, Issue 1, 2001, 16-35

[70] Ndubisi, N. O., Malhotra, N. K., and Wah, C. K., Relationship marketing, customer satisfaction and loyalty: a theoretical and empirical analysis from an Asian perspective, Journal of International Consumer Marketing, 2009, 21:5-1 6.

[71] Laith Alrubaiee and Nahla Al-Nazer., Investigate the impact of relationship marketing orientation on customer loyalty: the customer's perspective, International Journal of Marketing Studies Vol. 2, No. 1, 2010, 267-277

[72] Christopher, M., Payne, A., Ballantyne, D., Relationship Marketing: Bringing Quality, Customer Service and Marketing Together (London, UK: Butterworth, 1993).

[73] Fox, A., Beyond contract: Work, power and trust relationships (London: Faber, 1974).

[74] Berry, L. L., Playing fair in retailing. Arthur Anderson, Retailing Issues Newsletter, 5, 5, 1993).

[75] Delgado-Ballester, E., \& Munuera-Aleman, J. L.. Brand trust in the context of consumer loyalty. European Journal of Marketing, 35(11/12), 2001, 1238-1258.

[76] Chaudhuri, A., \& Holbrook, M. B., The chain of effects from brand trust and brand affect to brand performance: the role of brand loyalty. Journal of Marketing, 65, 2001, 81-93.

[77] Sirdeshmukh, D., Singh, J., \& Sabol, B.,. Consumer trust, value, and loyalty in relational exchanges. Journal of Marketing, 66(1), 2002,15-37.

[78] Harris, L. C., \& Goode, M. M. H., The four levels of loyalty and the pivotal role of trust: a study of online service dynamics. Journal of Retailing, 80(2), 2004, 139-158.

[79] Reichheld, F., , The one number you need to grow, Harvard Business Review 81, December, 2003, 46-54.

[80] Evanschitzky, H., \& Wunderlich, M., An examination of moderator effects in the four-stage loyalty model. Journal of Service Research, 8(4), 2006, 330-345.

[81] Pritchard, M. P., Haviz, M. E., and Howard, D. R., Analyzing the commitment-loyalty link in service contexts, Journal of Academy of Marketing Science, 27, 1999, 333-348

[82] Caceres, R. C. and Paparoidamis, N. G., Service quality, relationship satisfaction, trust, commitment and business-to-business loyalty, European Journal of Marketing, Vol. 41 No. 7/8, 2007, 836-867

[83] Price, L. L., and Arnould, E. J., Commercial friendships: service provider- client relationships in context. Journal of Marketing, 63(4), 1999, 38-56.

[84] Brown, T., Barry, T., Dacin, P., and Gunst, R., Spreading the word: investigating antecedents of consumers' positive word of mouth intentions in a retailing context. Journal of the Academy of Marketing Science 33 (2), 2005,123-138.

[85] Čater, Tomaž and Čater, Barbara, Product and relationship quality influence on customer commitment and loyalty in B2B manufacturing relationships, Industrial Marketing Management 39, 2010,1321-1333

[86] Oderkerken-Schroder, G., De Wulf, K. and Schumacher, P., Strengthening outcomes of retailer-consumer relationships: the dual impact of relationship marketing tactics and consumer personality, Journal of Business Research, Vol. 56, 2003, 177-90. 
[87] Michael, Nancy, Customer loyalty elusive, but critical, to create a cadre of customer advocates, focus your efforts on "the three Rs", Aba Banking Journal, February 2007, 42-46

[88] Leverin, Andreas and Liljander, Veronica, Does relationship marketing improve customer relationship satisfaction and loyalty?, International Journal of Bank Marketing Vol. 24 No. 4, 2006, 232-251

[89] Gaur, S. S., Xu, Y., Quazi, A., and Nandi, S., Relational impact of service providers' interaction behavior in healthcare, Managing Service Quality, Vol. 21 No. 1, 2011, 67- 87.

[90] Lee, Kun Chang and Chung, Namho, Understanding factors affecting trust in and satisfaction with mobile banking in Korea: A modified DeLone and McLean's model perspective, Interacting with Computers 21, 2009, 385-392

[91] Dagger, T. S. a nd O'Brien, Timothy K., Does experience matter? Differences in relationship benefits, satisfaction, trust, commitment and loyalty for novice and experienced service users, European Journal of Marketing, Vol. 44 No. 9/10, 2010, 1528-1552

[92] De Wulf, K., Odekerken-Schröder, G. and Schumacher, P., Why it takes two to build successful buyer-seller relationships, Working Paper No. 00/89, Ghent: Ghent University, 2000.

[93] Abdul-Muhmin, Alhassan G., Instrumental and interpersonal determinants of relationship satisfaction and commitment in industrial markets, Journal of Business Research, 58, 2005, 619-628

[94] Kim, W., Ok, C., and Gwinner, K. P., The antecedent role of customer-to- employee relationships in the development of customer-to-firm relationships. The Service Industries Journal, Vol. 30, No. 7, July 2010, 1139-1157

[95] Bollen, K.A., Structural Equations with Latent Variables (New York: John Wiley \& Sons, 1989).

[96] Hoyle, R., Structural Equation Modeling: Concepts, Issues, and Applications (Thousand Oaks: Sage Publications, 1995).

[97] Baron, R.M. and Kenny, D.A., The moderator-mediator variable distinction in social psychological research: conceptual, strategic and statistical considerations, Journal of Personality and Social Psychology, Vol. 51 No. 6, 1986, $1173-82$.

[98] Oliver, R. L., Whence Consumer Loyalty?, Journal of Marketing, Vol 63 (special issue), 1999, 33-34

[99] Howard, D. R., Edginton, C. R., and Selin, S. W., Determinants of program loyalty. Journal of Park and Recreation Administration, 6, 1988, 41-51.

[100] Iwasaki Y. \& Havitz,M. E., Examining relationships between leisure involvement, psychological commitment and loyalty to a recreation agency. Journal of Leisure Research, 36, 2004, 45-72.

[101] Morais, D. B., Dorsch, M. J., and Backman, S. J., Can tourism providers buy their customers' loyalty? Examining the influence of customer-provider investments on loyalty. Journal of Travel Research, 42, 2004, 235-243

[102] Podsakoff, P. M., MacKenzie, S. B., Moorman, R. H., \& Fetter, R., Transformational leader behaviors and their effects on followers' trust in leader, satisfaction, and organizational citizenship behaviors. Leadership Quarterly, 1, 1990,107-142.

[103] Pillai, R., Schriesheim, C. A., \& Williams, E., Fairness perceptions and trust as mediators for transformational and transactional leadership: A two-sample study, Journal of Management, 25(6), 1999, 897-934.

[104] Morrison, E.W. and Phelps, C., Taking charge: extra-role efforts to initiate workplace change, Academy of Management Journal, Vol. 42 No. 4, 1999, 403-19.

[105] Di, E., Huang C-J., Chen I-H and Yu T-C., Organisational justice and customer citizenship behaviour of retail industries The Service Industries Journal Vol. 30, No. 11, September 2010, 1919-1934

[106] Hoffman, B.J., Blair, C.A., Meriac, J.P. and Woehr, D.J., Expanding the criterion domain? A quantitative review of the OCB literature, Journal of Applied Psychology, Vol. 92 No. 2, 2007, 555-66.

[107] Cross, Richard and Janet Smith, Customer Bonding (Chicago, IL: NTC Business Books, 1995).

[108] Reichheld, The ultimate question: driving good profits and true growth (Boston, MA: Harvard Business School Press, 2006). 